\title{
Ketenagakerjaan Bagi Penyandang Disabilitas di Kota Padang
}

\author{
Harbi Sadri, Henni Muchtar \\ Prodi Pendidikan Pancasila dan Kewarganegaraan \\ FIS Universitas Negeri Padang \\ E-mail: harbisadri@gmail.com
}

\section{ABSTRAK}

Penelitian ini bertujuan untuk memperoleh gambaran mengenai bentuk,hasil dan faktor yang mempengaruhi pemberian kesempatan kerja dan pemenuhan kuota mempekerjakan penyandang disabilitas pada Instansi Daerah Kota Padang berdasarkan Perda Kota Padang No. 3 tahun 2015 tentang Penyandang Tentang Pemenuhan dan Perlindungan Hak-Hak Penyandang Disabilitas pasal 29 huruf a dan b. Penelitian ini menggunakan metode kualitatif pendekatan deskriptif dengan teknik pengumpulan data, observasi, wawancara, dokumentasi. Teknik penentuan informan menggunakan teknik Purposive Sampling, terdiri dari BKPSDM Kota Padang dan beberapa disabilitas. Hasil penelitian ini menunjukan bahwa bentuk pemberian kesempatan kerja bagi penyandang disabilitas di Instansi Daerah Kota Padang adalah melakukan perekrutan ASN jalur formasi khusus disabilitas. dan hasil dari pelaksanaannya adalah pemberian kesempatan kerja tersebut masih sangat minim dan terbatas dan kurang maksimal serta letak pengambilan keputusan yang bukan berada pada Pemerintahan Kota Padang dan banyaknya penyandang disabilitas yang tidak memenuhi ambang batas nilai kelulusan menjadi faktor kurang maksimalnya pemberian kesempatan kerja dan pemenuhan kuota 2\% mempekerjakan penyandang disabilitas di Kota Padang.

\section{Kata Kunci: ketenagakerjaan, penyandang disabilitas, Kota Padang}

\section{ABSTRACT}

This Study aims to obtain an overview of the form, the results and the factors that affect the provision of employment opportunities and the fulfillment of the quota of hiring people with disabilities at the Regional Agencies of the City of Padang is based on the Regulation of the City of Padang No. 3 year 2015 on the Disabled About the Fulfillment and Protection of the Rights of Persons with Disabilities article 29 of the letters $a$ and $b$. This research method using qualitative descriptive approach with data collection techniques, observation, interview, documentation. The technique of determination of informants using Purposive Sampling technique, consisting of BKPSDM Kota Padang and multiple disabilities. The results of this study showed that the form of the provision of employment opportunities for persons with disabilities in the Regional Agencies of the City of Padang is recruiting ASN pathways of the formation of a special disability. and the results of its implementation is the provision of employment opportunities is still very minimal and limited and less than the maximum as well as the layout of decision-making that are not in 
the Government of the City of Padang and the number of people with disabilities who do not meet the threshold value of the graduation to be a factor less optimal provision of employment opportunities and the fulfillment of the quota to $2 \%$ of hiring persons with disabilities in the City of Padang.

\section{Keywords: employment, persons with disabilities, Padang City}

This work is licensed under the Creative Commons Attribution-ShareAlike 4.0 International License. (C)2021 by author.

\section{PENDAHULUAN}

Hak atas pekerjaan merupakan bagian dari Hak Asasi Manusia yang telah dijamin oleh Undang-Undang Dasar Negara Republik Indonesia Tahun 1945. Yaitu pasal 27 ayat 3 yang berbunyi "Tiap-tiap warga negara berhak atas pekerjaan dan penghidupan yang layak". Berdasarkan hal tersebut maka sudah seharusnya setiap orang wajib menjunjung tinggi hak atas pekerjaan tanpa adanya diskriminasi apapun karena untuk mendapatkan penghidupan yang layak setiap orang pasti membutuhkan pekerjaan. Pada saat ini Kondisi Ketenagakerjaan di Indonesia masih memiliki permasalahan. Salah satu yang masih memiliki permasalahan yang layak untuk diteliti adalah kesenjangan pekerja disabilitas di Indonesia. Kondisi hal ini sebagaimana yang disampaikan oleh menteri ketenagakerjaan Ida Fauziyah (juli 2020) melalui media digital bahwa masih terdapat kesenjangan pekerja disabilitas di Indonesia yaitu hingga juli 2020 tingkat penganguran terbuka (TPT) penyandang disabilitas masih cukup tinggi yakni sebanyak 289.000 orang. (Kementrian ketenagakerjaan RI, 2020: 7). $\begin{array}{ccr} & \text { Dalam dunia kerja } \\ \text { penyandang disabilitas } & \text { sering }\end{array}$ dianggap sebagai pribadi yang tidak cakap dalam bekerja dan menjadi beban dari masyarakat serta tidak mampu untuk mandiri sehingga Penyandang disabilitas kerap kali sulit untuk mendapatkan pekerjaan (Geminasti Purinami dkk, 2018: 234). Menurut Ketua Komisi IV DPRD Kota Padang periode 2019-2024 yaitu bapak Azwar Siry (2020) melalui wawancara menyampaikan bahwa Dilihat secara fisik penyandang disabilitas memang memiliki kekurangan. Namun bukan berarti semua penyandang disabilitas itu tidak memiliki kemampuan. Karena sejatinya dibalik kekurangan setiap manusia pasti ada kelebihan yang dapat dimanfaatkan. Maka sudah seharusnya penyandang disabilitas layak diberikan kesempatan kerja dengan pertimbangan pada kemampuannya bukan pada kekurangan fisiknya. Kemudian pemberian kesempatan kerja tersebut harus disesuaikan juga dengan kondisi kedisabilitasannya agar mereka bisa maksimal dalam bekerja.

Pemerintah RI telah mengeluarkan aturan hukum untuk 
melindungi hak-hak penyandang disabilitas yaitu UU No. 8 Tahun 2016 Tentang Penyandang Disabilitas. Pada pasal 11 dalam UU No. 8 Tahun 2016 Tentang Penyandang Disabilitas dijelaskan beberapa hak penyandang disabilitas dalam hal pekerjaan, kewirausahaan dan koperasi. Pasal 11 huruf a diatur jelas bahwa penyandang disabilitas mempunyai hak "memperoleh pekerjaan yang diselenggarakan oleh pemerintah pusat, pemerintah daerah atau swasta tanpa diskriminasi". Kemudian ditingkat daerah perlindungan terhadapa hak-hak penyandang disabilitas juga sudah dibentuk aturannya. Salah satunya adalah Kota Padang dengan mengeluarkan Perda Kota Padang No. 3 Tahun 2015 Tentang Pemenuhan dan Perlindungan Hak-hak Penyandang Disabilitas. Pada Perda Tesebut terdapat aturan yang mengatur kewajiban Pemerintah daerah untuk mempekerjakan penyandang disabilitas yaitu Pasal 29 huruf a "memberikan kesempatan dan perlakuan yang sama kepada penyandang disabilitas untuk memperoleh pekerjaan sesuai dengan jenis dan derajat kedisabilitasan." dan Pasal 29 Huruf b "mempekerjakan 1 (satu) orang penyandang disabilitas yang memenuhi persyaratan dan kualifikasi pekerjaan sebagai pegawai untuk setiap 100 (seratus ) orang pegawai"

Meskipun sudah ada Perda Kota Padang No. 3 Tahun 2015 Tentang Pemenuhan dan Perlindungan Hak-hak Penyandang Disabilitas, pemberian kesempatan kerja bagi penyandang disabilitas nyatanya masih belum maksimal. Hal tersebut dapat dilihat dari penelitian yang dilakukan oleh Geni dkk (2019) tentang Implementasi Kebijakan Publik Mengenai Pemenuhan dan Perlindungan Hak Tenaga Kerja Disabilitas di Kota Padang. Hasil penelitian menunjukan bahwa implementasi Perda Kota Padang No. 3 tahun 2015 Tentang Pemenuhan dan Perlindungan HakHak Penyandang Disabilitas belum maksimal. Hal tersebut dapat dilihat dari hasil penelitian yaitu dari 100 responden hanya 13 lembaga pemerintahan dan 4 Lembaga Non Pemrintahan saja yang telah mempekerjakan penyandang disabilitas. Lenggo Geni sebagai peneliti yang melakukan survey menuturkan bahwa terdapat 78 Lembaga/Perusahaan di Kota Padang yang belum memperkerjakan penyandang disabilitas dan 5 lembaga mengaku tidak mengetahui adanya kewajiban untuk mempekerjakan penyandang disabilitas.

Berdasarkan penjabaran diatas maka peneliti sangat tertarik Untuk Melakukan penelitian tentang Ketenagakerjaan bagi Penyandnag Disabilitas di Kota Padang dengan memfokuskan pada bagaimana bentuk, hasil dan faktor yang mempengaruhi pemerintah kota padang dalam pemberian kesempatan kerja dan pemenuhan kuota mempekerjakan penyandang disabilitas pada Instansi Daerah Kota Padang berdasarkan Perda Kota Padang No. 3 tahun 2015 tentang Penyandang Tentang Pemenuhan dan Perlindungan Hak-Hak Penyandang Disabilitas pasal 29 huruf a dan b. Tujuan dari penelitian ini adalah untuk mengidentifikasi bentuk, hasil dan faktor yang mempengaruhi pemberian kesempatan kerja dan 
pemenuhan kuota mempekerjakan penyandang disabilitas pada Instansi Daerah Kota Padang berdasarkan Perda Kota Padang No. 3 tahun 2015 Tentang Pemenuhan dan Perlindungan Hak-Hak Penyandang Disabilitas pasal 29 huruf a dan b. Adapaun manfaat dari penelitian ini adalah untuk memberikan gambaran dan masukan pada pemerintah agar lebih memaksimalkan Implementasi Perda Kota Padang No. 3 tahun 2015 tentang Penyandang Tentang Pemenuhan dan Perlindungan HakHak Penyandang Disabilitas pasal 29 huruf $a$ dan $b$

\section{METODE PENELITIAN}

Penelitian ini merupakan penelitian kualitatif dengan menggunakan pendekatan deskriptif. Teknik pengumpulan data yang digunakan berupa wawancara, observasi dan dokumentasi (Sugiyono, 2016: 193) Informan pada penelitian ini terdiri dari BKPSDM Kota Padang, Dinas Sosial Kota Padang dan DPRD Kota Padang serta beberapa disabilitas. Uji Validitas pada penelitian ini menggunakan teknik triangulasi yaitu triangulasi sumber (Mudjia Rahardjo, 2012). Sedangkan teknik analisis data yang digunakan terdiri dari pengumpulan data, reduksi data, penyajian data dan penarikan kesimpulan(Sugiyono (2011:246). Hal ini penulis gunakan untuk mengidentifikasi Bentuk Implementasi Perda Kota Padang No. 3 Tahun 2015 Tentang Penyandang Disabilitas, pasal 29 huruf a sampai c.

HASIL DAN PEMBAHASAN Kesempatan Kerja Dan Pemenuhan Kuota Mempkerjakan Penyandang Disabilitas
Kewajiban memberikan kesempatan kerja dan memenuhi kuota mempekerjakan penyandang disabilitas di Pemerintahan Kota Padang diatur dengan jelas dalam Perda Kota Padang No. 3 Tahun 2015 Tentang Pemenuhan dan Perlindungan Hak-hak Penyandang Disabilitas, Pasal 29 huruf a "memberikan kesempatan dan perlakuan yang sama kepada penyandang disabilitas untuk memperoleh pekerjaan sesuai dengan jenis dan derajat kedisabilitasan" dan Pasal 29 Huruf b "mempekerjakan 1 (satu) orang penyandang disabilitas yang memenuhi persyaratan dan kualifikasi pekerjaan sebagai pegawai untuk setiap 100 (seratus) orang pegawai. Namum untuk saat ini terkait kuota mempekerjakan penyandang disabilitas di pemerintahan kota padang, Perda Kota Padang No. 3 Tahun 2015 Tentang Pemenuhan dan Perlindungan Hak-hak Penyandang Disabilitas pasal 29 huruf b sudah tidak digunakan aturan yang dipakai adalah UU No. 8 Tahun 2016 tentang Penyandang Disabilitas pasal 53 ayat 1 yaitu : "pemerintah, Pemerintah Daerah, Badan Usaha Milik Negara, dan Badan Usaha Milik Daerah wajib mempekerjakan paling sedikit 2\%(dua persen) Penyandang Disabilitas dari jumlah pegawai atau pekerja."

Berdasarkan aturan diatas terlihat jelas bahwa Pemerintah Kota Padang memiliki kewajiban untuk memberikan kesempatan kerja dan memenuhi Kuota 2\% mempekerjakan penyandang disabilitas di lingkup pemerintahan daerah. Pada hasil wawancara dan observasi yang telah dilakukan didapati bahwa bentuk pemberian kesempatan kerja dan 
pemenuhan kuota 2\% mempekerjakan penyandang disabilitas dapat dilaksanakan dengan cara perekrutan ASN disabilitas melalui tes CPNS jalur formasi khusus disabilitas. jumlah kuota pada jalur formasi khusus disabilitas pada pemerintah Kota Padang ditetapkan oleh Kemenpan-RB berdasarkan 2\% dari jumlah formasi umum yang dibuka untuk Pemerintah Kota Padang. Sebelum melakukan perekrutan atau pengadaan ASN Pemerintah Kota Padang harus melakukan beberapa hal yaitu 1) menyusun kebutuhan jumlah dan jenis jabatan pegawai negeri sipil dilakukan untuk jangka waktu 5 (lima) tahun yang diperinci per 1 (satu) tahun berdasarkan prioritas kebutuhan jabatan. Penyusunan tersebut kemudian diserahkan oleh Instansi Daerah Kota Padang kepada Kemenpan-RB dan kepala BKN 2) melakukan redistribusi pegawai secara internal maupun lintas instansi, yang didasarkan pada hasil perhitungan kebutuhan Pegawai Negeri Sipil berdasarkan analisis jabatan dan analisis beban kerja. Dua hal yang djelaskan diatas wajib dilakukan oleh pemerintah Kota Padang guna Badan Kepegawaian Negara (BKN) dapat memberikan pertimbangan kepada Kemenpan RB dalam menetapkan jumlah formasi yang dibuka untuk Instansi Daerah Kota Padang.

Berdasarkan hasil wawancara dan observasi didapati bahwa hasil pemberian kesempatan kerja dan pemenuhan kouta $2 \%$ mempekerjakan penyandang disabilitas pada Instansi Daerah Kota Padang belum maksimal. Semenjak diberlakukannya Perda Kota Padang No. 3 Tahun 2015 Tentang Pemenuhan dan
Perlindungan Hak-hak Penyandang Disabilitas, Pemberian kesempatan kerja terhadap penyandang disabilitas melalui formasi khusus disabilitas sudah dibuka sebanyak 2 kali yaitu pada Tes CPNS tahun 2018 dan tahun 2020. Namun Tahun 2018 tidak mencapai kuota 2\% dan tahun 2020 sudah mencapai kuota $2 \%$. Berikut ini disajikan tabel riwayat formasi pada Tes CPNS untuk Instansi Daerah Kota Padang 6 tahun terakhir sebagai berikut :

Tabel. 1 : Riwayat Formasi Pada Tes CPNS Untuk Instansi Daerah Kota Padang

\begin{tabular}{|l|c|c|c|}
\hline No. & Tahun & Formasi Umum & $\begin{array}{c}\text { Formasi Khusus } \\
\text { Disabilitas }\end{array}$ \\
\hline 1 & 2015 & 30 orang & - \\
\hline 2 & 2016 & - & - \\
\hline 3 & 2017 & - & - \\
\hline 4 & 2018 & 558 orang & 5 orang \\
\hline 5 & 2019 & - & - \\
\hline 6 & 2020 & 374 Orang & 7 orang \\
\hline
\end{tabular}

Sumber: Data BKPSDM Kota Padang 2020

Berdasarkan tabel diatas terlihat jelas bahwa pada tahun 2018 berdasarkan kuota $2 \%$ dari jumlah formasi umum, formasi disabilitas yang dibuka seharusnya adalah sebanyak 10 orang, namun kenyataannya pada tahun tersebut hanya dibuka 5 formasi khusus disabilitas. sedangkan pada tahun 2020 Pemerintah Kota Padang sudah mencukupi kuota 2\% mempekerjakan penyandang disabilitas. Setelah dilakukan observasi lebih mendalam didapati bahwa Pada tahun 2018 ternyata 2 dari 5 orang yang dinyatakan lulus Menjadi CPNS jalur formasi khusus disabilitas bukanlah penyandang disabilitas, hal ini terjadi karena hanya 3 orang penyandang disabilitas yang mencukupi nilai ambang kelulusan, kemudian. 
Volume 4 No. 22021

Kemudian tercatat sampai tahun 2020 terdapat 19 ASN Penyandang Disabilitas yang masih aktif bekerja di instansi Daerah Kota Padang. 19 orang Tersebut terdiri atas 6 orang diterima sejak tahun 2010, 1 orang korban gempa, 5 orang tahun 2019 (tes CPNS 2018) dan 7 orang tahun 2020 yang saat ini masih berstatus CPNS.

Dilihat berdasarkan jumlah Pemberian kesempatan kerja bagi penyandang disabilitas untuk Instansi Daerah Kota Padang memang masih sangat minim. Namun perlu diketahui setiap Implementasi kebijakan publik pasti terdapat beberapa hal yang sangat mempengaruhi keberhasilan dari Implementasi Tersebut.

Menurut Teori Grindlle (Leo Agustino 2016:142) terdapat 2 variabel yang sangat mempengaruhi impelemntasi kebijakan publik yaitu variabel isi kebijakan yang terdiri dari 6 jenis dan variabel lingkungan implementasi yang terdiri atas 3 jenis. Pada penelitian ini variabel yang sangat berpengaruh adalah variabel isi kebijakan. jenis yang sangat berpengaruh ialah letak pengambilan keputusan dan tingkat perubahan yang diinginkan oleh suatu kebijakan.

Berdasarkan hasil wawancara dan observasi yang telah dilakukan Terdapat beberapa hal yang menjadi faktor penghambat pemberian kesempatan kerja dan pemenuhan kuota $\quad 2 \% \quad$ mempekerjakan penyandang disabilitas di instansi daerah kota padang yaitu : 1) letak pengambilan keputusan : yang berhak mengambil keputusan terkait penerimaan dan penetapan jumlah formasi CPNS jalur formasi khusus disabilitas adalah Badan Kepegawaian Negara dan Kemenpan-RB,
Pemerintaha Kota Padang Hanya memberikan usulan dan laporan guna BKN dapat memetakan Jumlah ASN yang dibutuhkan untuk Instansi Daerah Kota Padang hal ini dilaksanakan berdasarkan ketentuan yang berlaku, letak pengambilan keputusan yang bukan berada pada Instansi Daeah Kota Padang Tersebutlah yang menyebabkan terbatasnya penerimaan penyandang disabilitas. 2) tingkat perubahan yang diinginkan oleh suatu kebijakan : berdasarkan UU No. 8 tahun 2016 tentang Penyandang Disabilitas pasal 53 ayat 1 mengindikasikan bahwa pemerintah harus mempekerjakan penyandang disabilitas $2 \%$ dari jumlah formasi umum namun pada tahap pelaksanaan ternyata banyak penyandang disabilitas yang tidak memenuhi ambang batas nilai kelulusan sehingga menyebabkan minimnya penyandang disabilitas yang bekerja di Instansi Daerah Kota Padang. hal ini dapat disimpulkan bahwa tingkat peubahan yang diinginkan kebijakan tersebut masih terlalu tinggi dan tidak sesuai dengan keadaan disabilitas di Indonesia.

Berkaitan dengan bentuk pemberian kesempatan kerja dan pemenuhan kuota $2 \%$ mempekerjakan penyandang disabilitas Pada Instansi Daerah Kota Padang. pada penelitian lain yaitu penelitian yang dilakukan oleh Masrudi Muchtar Dkk (2020) dengan judul Evaluasi Penerimaan CPNS Bagi Penyandang Disabilitas di Pemerintah Provinsi Kalimantan Selatan juga dijelaskan bahwa penyandang disabilitas dapat bekerja di pemerintahan daerah melalui Tes CPNS jalur formasi Khusus disabilitas. namum terkait bentuk tersebut Masrudi Dkk menjelaskan hal 
yang berbeda dengan yang penulis jelaskan yaitu pemerintah daerah harus melakukan beberapa hal yakni :1) Melakukan penyamaan persepsi antar pemerintah pusat, pemerintah daerah dan pihak terkait lainnya, 2) Menyusun formasi penyandang disabilitas berdasarkan kebutuhan daerah dan penyandang disabilitas, 3 ) Mengoptimalkan pelayanan bagi penyandang disabilitas.

Sama halnya dengan hasil penelitian ini terkait hasil pemberian dan pemenuhan kuota mempekerjakan penyandang disabilitas pada pemerintahan Penelitian yang dilakukan oleh Endang \& Rini (2020) tentang Pemenuhan Hak Aparatur Sipil Negara (ASN) Penyandang Disabilitas di Pemerintah Provinsi DKI Jakarta juga menunjukan hasil yang hampir serupa yaitu kurang maksimalnya pemberian kesempatan kerja bagi Penyandang disabilitas di pemerintahan Provinsi DKI Jakarta. Hal tersebut dapat terlihat pada tes CPNS tahun 2018 yaitu Pemprov DKI jakarta sudah mengalokasikan sebanyak 65 formasi untu k disabilitas, namun sampai pada tahap akhir hanya terdapat 23 orang yang dinyatakan lolos sebagai CPNS. Dilihat berdasarkan jumlah tersebut terlihat jelas bahwa formasi disabilitas pada tes CPNS 2018 masih banyak yang belum terisi.

\section{KESIMPULAN}

Berdasarkan hasil penelitian dapat penulis simpulkan bahwa bentuk dari pemberian kesempatan kerja bagi penyandang disabilitas di Instansi Daerah Kota Padang ialah melakukan perekrutan ASN melalui jalur Formasi Khsus disabilitas,
Sedangkan terkait hasil dari pelaksanaan pemberian kesempatan kerja bagi penyandang disabilitas di Instansi Daerah Kota padang didapati bahwa pemberian kesempatan kerja bagi penyandang disabilitas di Instansi daerah kota padang masih sangat minim yaitu hanya terdapat 19 disabilitas yang bekerja di Instansi Daerah Kota Padang dan dalam 6 tahun terakhir semenjak diberkalkukannya Perda Kota Padang No. 3 Tahun 2015 , Tes CPNS jalur formasi khusus disabilitas sudah dibuka 2 kali namun pada tahun 2018 tidak memenhui kuota dan jumlah formasi yang dibuka tidak mencapai $2 \%$. Adapun faktor yang mempengaruhinya adalah letak pengambilan keputusan yang bukan berada pada Pemerintah Kota Padang dan masih sedikitnya penyandang disabilitas yang memenuhi nilai ambang batas kelulusan.

\section{DAFTAR PUSTAKA}

Endang \& dini. (2020). Pemenuhan Hak Aparatur Sipil Negara (ASN) Penyandang

Disabilitas di Pemerintah Provinsi DKI Jakarta. Jurnal Ilmiah Manajemen FORKAMMA Vol 4:1

Geminasti Purinami Dkk. (2018). Penyandang Disabilitas Dalam Dunia Kerja. Jurnal Pekerjaan sosial vol $1: 3$

Geni dkk. 2019. Implementasi Kebijakan Publik Mengenai Pemenuhan dan Perlindungan Hak Tenaga Kerja Disabilitas di Kota Padang. Padang : 
Perkumpulan Penyandang

Disabilitas Indonesia (wilayah padang).

Kementerian Ketenagakerjaan RI. 2020. Kliping Berita Ketenagakerjaan 15 Desember 2020. Jakarta : biro hubungan masyarakat.

Leo Agustino. 2016. Dasar-Dasar Kebijakan Publik. Bandung. Alfabeta

Masrudi Muchtar Dkk. (2020). Evaluasi Penerimaan CPNS Bagi Penyandang Disabilitas di Pemerintah Provinsi Kalimantan Selatan. Jurnal Kebijakan Pembangunan Vol 15 :2

Mudjia Rahardjo. 2010. Triangulasi dalam Penelitian Kualitatif. Bahan Ajar Perkuliahan.
Sugiyono. (2016). Metode Penelitian

Kuantitatif, Kualitatif dan R\&D. Bandung: PT Alfabet.

Sugiyono. 2011. Metode Penelitian

Kuantitatif, Kualitatif dan

R\&D. Bandung: Afabeta

Undang-Undang Dasar Negara Republik Indonesia Tahun 1945.

UU No. 8 Tahun 2016 Tentang Penyandang Disabilitas

UU No. 5 tahun 2015 Tentang Aparatur Sipil Negara

Perda Kota Padang No. 3 Tahun 2015 Tentang Pemenuhan dan Perlindungan Hak-hak Penyandang Disabilitas. 